The Israeli Journal of Aquaculture - Bamidgeh, IJA_69.2017.1382, 9 pages

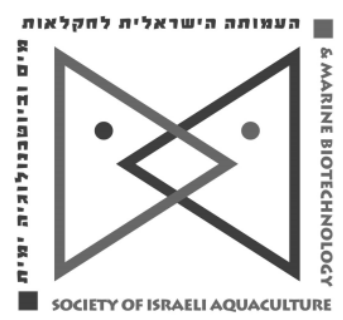

The IJA appears exclusively as a peer-reviewed on-line open-access journal at http://www.siamb.org.il. To read papers free of charge, please register online at registration form.

Sale of $I J A$ papers is strictly forbidden.

\title{
Effects of Substitution of Fish Meal with Black Soldier Fly (Hermetia illucens) Larvae Meal, in Yellow Catfish (Pelteobagrus fulvidraco) Diets
}

\author{
Junru Hu ${ }^{1,2}$, Guoxia Wang ${ }^{1,2}$, Yanhua Huang ${ }^{1,2^{*}}$, Yuping Sun ${ }^{1,2}$, Fei \\ $\mathrm{He}^{3}$, Hongxia Zhao ${ }^{1,2}$, Nana $\mathrm{Li}^{3}$ \\ ${ }^{1}$ Institute of Animal Science, Guangdong Academy of Agricultural \\ Sciences, Guangzhou 510640, P. R. China \\ 2 State Key Laboratory of Livestock and Poultry Breeding, Guangdong \\ Academy of Agricultural Sciences, Guangzhou 510640, P. R. China \\ ${ }^{3}$ Guang zhou fishtech co., LTD, Guangzhou 510640, P. R. China
}

Keywords: fishmeal; black soldier fly larvae meal; Pelteobagrus fulvidraco; growth; apparent digestibility; plasma parameters

\begin{abstract}
An 8-week feeding trial was conducted to evaluate effects of replacing fish meal (FM) with black soldier fly larvae meal (BSF) on growth performance, feed utilization, and plasma parameters, for juvenile yellow catfish, Pelteobagrus fulvidraco. Six isonitrogenous and isolipidic diets were prepared substituting the FM protein with BSF protein in the following amounts: 0 (control group), 10\% (BSF10), 15\% (BSF15), 20\% (BSF20), 25\% (BSF25) and $30 \%$ (BSF30). Three replicate groups of juvenile yellow catfish (initial weight of $1.20 \pm 0.01 \mathrm{~g}$ ) were stocked in circular tanks at a rate of 30 fish per tank. The results showed that $20 \%$ of the FM in the control diet could be replaced with BSF without significantly reducing weight gain, feed conversion ratio, or whole body and muscle proximate composition. Apparent digestibility coefficients (ADCs) of dry matter, crude protein, crude lipids, gross energy, or amino acids were not affected by $10 \% \mathrm{FM}$ replacement. $30 \% \mathrm{FM}$ replacement in the BSF30 diet significantly increased the concentration of cholesterol (CHO) and nitric oxide (NO) in the plasma, and significantly reduced the inhibition of superoxide radical anion formation. In conclusion, it appears that up to $20 \%$ of the FM in conventional yellow catfish diets can be replaced with $\mathrm{BSF}$, and thus account for up to $8.9 \%$ of the total protein in the diet without causing a significant reduction in growth performance.
\end{abstract}

* Corresponding author. Y.H Huang; Tel.: +86 2061368836, fax: +86 2061368836, email: Huangyh111@126.com 
Hu et al.

\section{Introduction}

Yellow catfish Pelteobagrus fulvidraco is an omnivorous freshwater fish that is extensively cultured in China, where it is popular with consumers because of its flavorsome and smoothly textured flesh. Cultured yellow catfish are predominantly fed commercially manufactured feed, and because juvenile yellow catfish require a protein intake of between 375.8 and $403.8 \mathrm{~g} / \mathrm{kg}$ dry diet, they are frequently fed with high-grade fish meal (FM). However, supplies of this protein source are limited, and its price has risen significantly in recent years (http://www.globefish.org), substantially increasing the cost of fish production. It is therefore beneficial to replace FM with suitable alternative plant or animal protein sources to ensure profitability.

The black soldier fly (BSF) Hermetia illucens L. (Diptera: Stratiomyidae) is found in warm regions worldwide. The larvae feed on decomposing organic material such as fruit and vegetable waste, as well as manure, and convert the nutrients and energy in these waste materials into biomass. Grown larvae reportedly have protein and fat content of $36-48 \%$ and $31-33 \%$, respectively (St-Hilaire et al., 2007a), and could be an excellent source of protein to replace FM in aquaculture (Bondari \& Sheppard 1981). BSF is used as dietary protein in commercial fish species such as channel catfish Ictalurus punctatus (Bondari \& Sheppard 1981), tilapia Oreochromis niloticus (Bondari \& Sheppard 1981; Rana et al., 2015; Hem et al., 2008), Clarias gariepinus (Adeniyi et al.,2015), rainbow trout Oncorhynchus mykiss (St-Hilaire et al., 2007a; Sealey et al., 2011; Stamer et al., 2014), juvenile turbot Psetta maxima (Kroeckel et al., 2012) and Pacific white shrimp Litopenaeus vannamei (Cummins et al., 2017). Although these studies yielded interesting results, use of BSF is not yet widespread in yellow catfish.

The aims of this study were: (1) to evaluate the effect of replacing FM with BSF on the growth performance, apparent nutrient digestibility, and whole body and muscle composition of juvenile yellow catfish; and (2) evaluate the plasma parameters of juvenile yellow catfish fed on diets including BSF.

\section{Materials and Methods}

Experimental Diets. The formulation and chemical composition of the test diets and feedstuffs used in this study are shown in Tables 1 and 2, respectively. The dietary components and the basal diet were similar to those used in a recent commercial diet. All of the dietary components were obtained from commercial sources. A control diet in which FM (protein, $62.3 \%$; lipid, $8.1 \%$ ) served as protein source was supplied by Guangzhou Fishtech Fisheries Science \& Technology Co. (China). The five isonitrogenous and isolipidic experimental where BSF replaced fishmeal were; $10 \%$ (BSF10), 15\% (BSF15), 20\% (BSF20), 25\% (BSF20), and 30\% (BSF30). The control diet included only FM. BSF larvae were cultivated by placing BSF eggs on a $250 \mu \mathrm{m}$ mesh, which was then placed on top of a plastic box containing wet wheat in a manner so the hatched larvae fell through the mesh onto the bran. After three days the larvae were transferred to a culture bed containing crushed kitchen waste; after eight days on the bed, they were ready for harvesting. The harvested larave were dried in an oven at $103^{\circ} \mathrm{C}$ for ten hours and then at $85^{\circ} \mathrm{C}$ for twelve hours, during which they were periodically stirred. The dried larvae were then pulverized to form a meal with a composition of crude protein and lipid of $33.25 \%$ and $33.45 \%$, respectively. Microelemental analysis indicated that the meal contained $6.0 \mathrm{mg} / \mathrm{kg} \mathrm{Cu}, 140.0 \mathrm{mg} / \mathrm{kg} \mathrm{Fe}, 53.0 \mathrm{mg} / \mathrm{kg} \mathrm{Zn}, 62.0 \mathrm{mg} / \mathrm{kg} \mathrm{Mn}, 16.4 \mathrm{mg} / \mathrm{kg}$ $\mathrm{F}$, and $0.69 \mathrm{mg} / \mathrm{kg} \mathrm{Cr}$. The meal's hygienic index had a bacterial count of $1.40 \times 10^{2}$ $\mathrm{CFU} / \mathrm{g}$ on a dry matter basis in confirmation with "Hygienical standards for feeds" in China. Yttrium oxide $\left(\mathrm{Y}_{2} \mathrm{O}_{3}\right.$; Analytical Reagent, Tianjin Guangfu Fine Chemical Research Institute, China) was added to the meal at a level of $0.04 \%$ as an inert dietary marker for the estimation of ADCs. The dietary ingredients were then ground into a fine powder and filtered through a $250 \mu \mathrm{m}$ mesh. The dry ingredients of the diets were mixed, first with micro ingredients and then by gradually adding the rest of the ingredients. Soybean oil, lecithin oil, and distilled water were then slowly added to the premixed dry ingredients until the mixture became homogeneous. The resulting mixture was pelleted with a $2 \mathrm{~mm}$ die, dried in an oven at $50^{\circ} \mathrm{C}$ until the moisture content was less than $10.0 \%$ and then stored in plastic bags at $-20^{\circ} \mathrm{C}$ until used. 
Table 1. Composition and nutrient levels of experimental diets ( $\mathrm{g} / \mathrm{kg}$ dry matter).

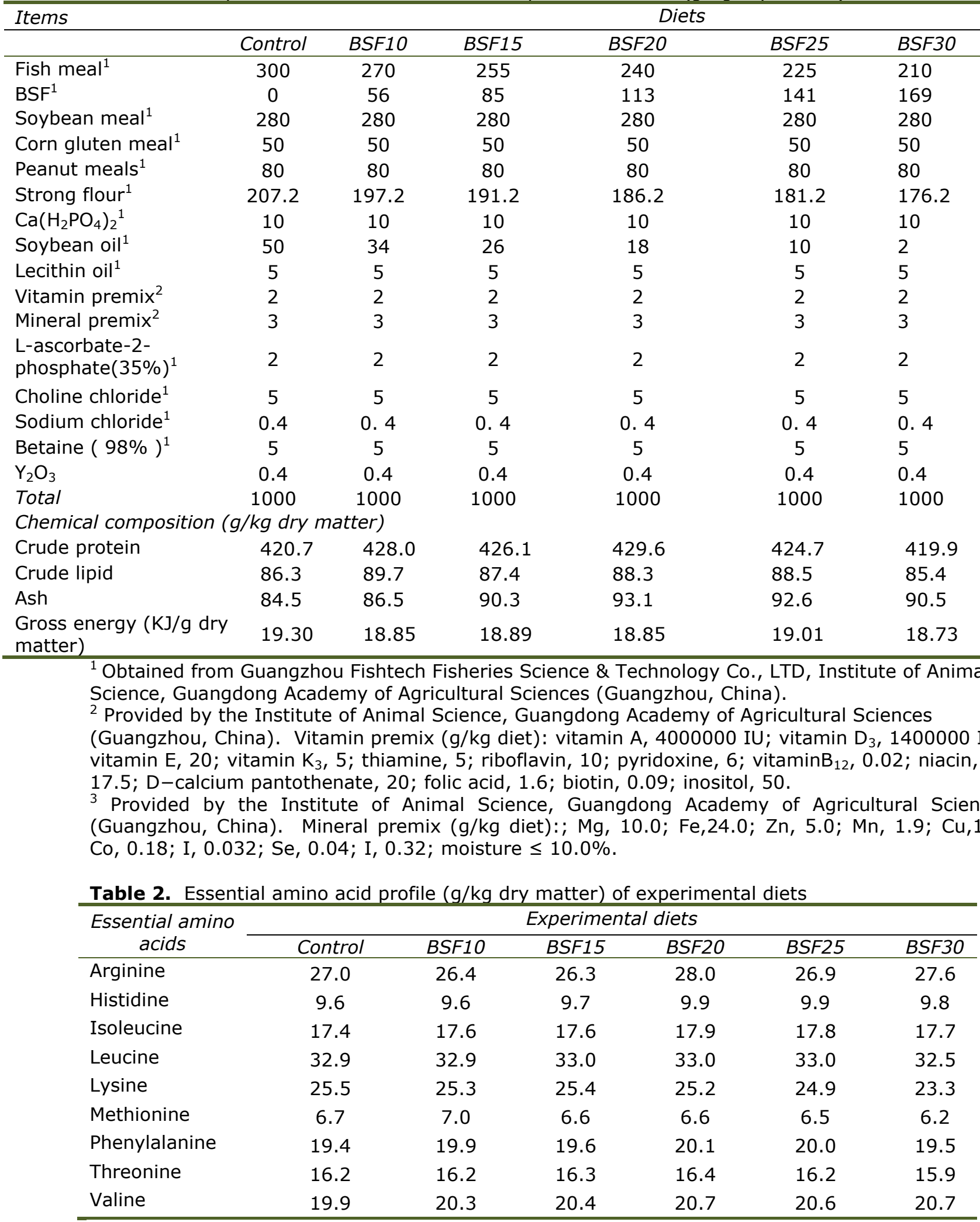


Feeding trials. The feeding trials were conducted in an indoor flow-through system. The ambient water temperature during the experiment ranged from $26-32^{\circ} \mathrm{C}$, reflecting changes in the external temperature. Dissolved oxygen content of the water was maintained above $6 \mathrm{mg} / \mathrm{L}$, the level of ammonia- $\mathrm{N}$ was maintained below $0.2 \mathrm{mg} / \mathrm{L}$, and the $\mathrm{pH}$ ranged from 7-7.5. A $12 \mathrm{~h}$ dark/12 $\mathrm{h}$ light photoperiod was maintained throughout the experiment. The juvenile yellow catfish used in the study were obtained from a private hatchery. Before the feeding trial, the fish were acclimated to the experimental conditions and fed a commercial diet (crude protein, 42.24\%; lipids, $7.06 \%$; ash, $10.06 \%$; moisture, $9.42 \%$ ) for 2 weeks. Fish with mean initial weights of $(1.20 \pm 0.01) \mathrm{g}$ were randomly distributed into 18 tanks (each having a capacity of $350 \mathrm{~L}$ and containing $300 \mathrm{~L}$ water), with 30 fish per tank. Each experimental diet was randomly assigned to three replicate tanks per diet. Each diet was fed to fish to satiation twice daily (9:00 am and 4:00 pm), and daily rations were adjusted based on prior feeding responses. There was little uneaten feed throughout the experiment. Any uneaten food at the end of the day was collected by siphoning. It was then dried and weighed. The resulting data was used to determine actual feed consumption and feed conversion ratio (FCR). After 8 week of feeding, feces were collected daily after feeding at (9:00 am and 4:00 pm) from the bottom of the tanks with a scoop net (178 $\mu \mathrm{m}$ mesh) and the tank bottom cleaned after each feeding. Fresh intact feces were placed in fecal traps, which were surrounded with ice to minimize bacterial degradation and stored at $-20^{\circ} \mathrm{C}$ until analysis. This process was conducted over two weeks to enable the gathering of sufficient fecal matter for chemical analysis.

Sample collection and biochemical analysis. A pooled sample of 10 fish was set aside at the start of the trial and stored at $-20^{\circ} \mathrm{C}$ for whole body analysis. After the 8 week feeding trial, all fish were fasted for $24 \mathrm{~h}$, weighed and counted. A pooled sample of five fish from each tank was randomly collected and stored at $-20^{\circ} \mathrm{C}$ for final whole body analysis. Six of the remaining fish from each tank were then selected randomly, anesthetized with diluted MS-222 (Ethyl 3-aminobenzoate methanesulfonate, Tricaine; Suzhou SciYoung BioMedicine Technology Co., Ltd) $(60 \mathrm{mg} / \mathrm{L})$, and samples of blood, liver and muscle samples were taken. Blood was drawn from the caudal vein with a syringe, transferred into a tube containing sodium EDTA as anticoagulant, then centrifuged immediately at $3500 \times \mathrm{g}$ for $10 \mathrm{~min}$ at $4^{\circ} \mathrm{C}$. The plasma was preserved at $-78^{\circ} \mathrm{C}$ for analysis of biochemical indices and antioxidant activity. The muscle tissue of the six fish was dissected and stored at $-20^{\circ} \mathrm{C}$ for nutrient composition analysis.

The diets, feces, whole fish bodies, and muscle samples were analyzed for moisture, crude protein, crude lipids, and ash in triplicate, using standard methods (AOAC, 1995). Samples of the diets and feces were dried to constant weight at $105^{\circ} \mathrm{C}$. Yttrium concentrations in diet and fecal samples were determined by atomic absorption spectrophotometer (ICP-AES) using a nitrous oxide-acetylene flame after acid digestion $(2 \%$ nitric acid and $2 \mathrm{~g} / \mathrm{L} \mathrm{KCl})$. The crude protein content $(\mathrm{N} \times 6.25)$ was determined by the Kjeldahl method with a semi-automatic Kjeldahl System (1030 Autoanalyzer, Tecator, Hoganos, Sweden) after acid digestion. The crude lipid content was determined by the ether extraction method with a Soxhlet System HT (Soxtec System HT6, Tecator, Sweden), and the ash content was determined by burning the samples at $550^{\circ} \mathrm{C}$ in a muffle furnace for $24 \mathrm{~h}$. The amino acid composition of the ingredients, diets, feces, and muscles of the fish were analyzed by HPLC (Agilent 1260, USA) after the samples were hydrolyzed in $6 \mathrm{~N} \mathrm{HCl}$ for $22 \mathrm{~h}$ at $110^{\circ} \mathrm{C}$. The gross energy content was determined with an IKA ballistic bomb calorimeter (C2000, Germany). Plasma biochemical indices determined with a fully automatic biochemical analyzer (HITACHI 7170A). Inhibition of superoxide radical anion generation and NO levels were assayed using commercial kits (Nanjing Jiancheng Bioengineering Institute, China. kit Cat.: A052, A012, A001-1) following the manufacturer's instructions. The protein concentration in liver supernatant samples was measured spectrophotometrically according to Bradford (1976) using bovine serum albumin as a standard. 
Evaluation of performance parameters. The following variables were evaluated:

Weight gain ratio $(W G R, \%)=100 \times($ final body weight - initial body weight )/initial body weight

Feed conversion ratio $(F C R)=$ feed fed $(\mathrm{g})$ /body weight gain $(\mathrm{g})$

Survival rate $(\%)=100 \times$ (final no. of fish/ initial no. of fish)

Apparent digestibility coefficient $(A D C, \%)=100-\left(100 \times\left(\% Y_{2} \mathrm{O}_{3}\right.\right.$ in diet $/ \% \mathrm{Y}_{2} \mathrm{O}_{3}$ in feces $) \times(\%$ nutrient in feces $/ \%$ nutrient in diet $)$.

Statistical analysis. All data are expressed as means \pm standard error and were subjected to one-way analysis of variance (ANOVA) after being checked for any violations of the ANOVA model. When overall differences were significant at $P<0.05$, the Fisher's Least Significant Difference (LSD) test was used to compare the means. All statistical analyses were performed using the SPSS 11.5 program (SPSS Inc, Chicago, IL, USA). The level of significant difference was set at $P<0.05$.

\section{Results}

Growth performance and feed utilization. The growth performance, feed utilization and survival of the fish fed on the different diets appear in Table 3. The final weight in BSF30 group, WGR in BSF25 and BSF30 groups, showed significantly lower values than in the control $(P<0.05)$, while, FCR in BSF30 groups showed the highest values $(P<0.05)$. Every group's survival rate was above $97 \%$, but that of the control group was significantly lower than those of the other groups $(P<0.05)$, except BSF15 $(P>0.05)$.

Apparent digestibility coefficient. Apparent digestibility coefficients (ADCs) of dry matter, crude protein, crude lipid, gross energy, and amino acids in the tested diets appear in Table 4. The ADCs were not significantly different from the control and the BSF10 group $(P>0.05)$, but the general trend of ADCs was lower as the FM replacement increased.

Whole body and muscle proximate composition. Data on the whole proximate body and muscle composition of the juvenile catfish fed the different diets appear in Table 5 . There were no significant differences in crude protein, crude lipid and moisture content in whole body and muscle $(P>0.05)$, while the ash content in muscle was slightly higher in the replacement groups and showed the highest values in BSF25 group which was significantly different from control group $(P<0.05)$. Methionine and phenylalanine were significantly lower $(P<0.05)$ in BSF25 group than in the control.

Plasma parameters. The measured plasma parameters for the juvenile yellow catfish appear in Table 6. The levels of $\mathrm{CHO}$ and NO were highest, while the inhibition of superoxide radical anion generation significantly decreased in the BSF30 group $(P<0.05)$ compared to the control.

Table 3. Growth performances and feed utilization of juvenile yellow catfish fed test diets for 8 weeks ${ }^{1}$.

\begin{tabular}{lllcll}
\hline Diet groups & $\begin{array}{l}\text { Initial } \\
\text { weight }(\mathrm{g})\end{array}$ & $\begin{array}{l}\text { Final weight } \\
(\mathrm{g})\end{array}$ & WGR $(\%)$ & FCR & $\begin{array}{l}\text { Survival rate } \\
(\%)\end{array}$ \\
\hline Control & 1.17 & $20.7 \pm 0.10^{\mathrm{a}}$ & $1656 \pm 12.5^{\mathrm{a}}$ & $0.74 \pm 0.01^{\mathrm{b}}$ & $97.8 \pm 1.11^{\mathrm{b}}$ \\
BSF10 & 1.19 & $20.6 \pm 0.40^{\mathrm{a}}$ & $1610 \pm 13.9^{\mathrm{ab}}$ & $0.76 \pm 0.01^{\mathrm{ab}}$ & $100 \pm 0.00^{\mathrm{a}}$ \\
BSF15 & 1.18 & $19.2 \pm 0.12^{\mathrm{ab}}$ & $1544 \pm 27.3^{\mathrm{ab}}$ & $0.79 \pm 0.02^{\mathrm{ab}}$ & $98.9 \pm 1.11^{\mathrm{ab}}$ \\
BSF20 & 1.19 & $19.8 \pm 0.37^{\mathrm{ab}}$ & $1590 \pm 35.3^{\mathrm{ab}}$ & $0.77 \pm 0.02^{\mathrm{ab}}$ & $100 \pm 0.00^{\mathrm{a}}$ \\
BSF25 & 1.18 & $19.5 \pm 0.44^{\mathrm{ab}}$ & $1529 \pm 29.4^{\mathrm{b}}$ & $0.80 \pm 0.02^{\mathrm{ab}}$ & $100 \pm 0.00^{\mathrm{a}}$ \\
BSF30 & 1.18 & $18.9 \pm 0.93^{\mathrm{b}}$ & $1498 \pm 77.2^{\mathrm{b}}$ & $0.82 \pm 0.04^{\mathrm{a}}$ & $100 \pm 0.00^{\mathrm{a}}$ \\
\hline
\end{tabular}

${ }^{1}$ Means of three replicate tanks. Values with different superscripts in columns are significantly different $(P<0.05)$ 
Table 4. Apparent digestibility coefficients (ADC) (\%) of nutrients in test diets consumed by juvenile yellow catfish ${ }^{1}$.

\begin{tabular}{|c|c|c|c|c|c|c|}
\hline \multirow{2}{*}{ Nutrients } & \multicolumn{6}{|c|}{ Diet groups } \\
\hline & Control & BSF10 & BSF15 & BSF20 & BSF25 & BSF30 \\
\hline Dry matter & $76.0 \pm 1.50^{a}$ & $74.4 \pm 1.35^{\mathrm{ab}}$ & $71.9 \pm 0.88^{b}$ & $72.7 \pm 0.00^{\mathrm{b}}$ & $73.6 \pm 0.00^{\mathrm{ab}}$ & $74.7 \pm 1.10^{\mathrm{ab}}$ \\
\hline Crude protein & $91.1 \pm 0.35^{\mathrm{a}}$ & $90.2 \pm 0.65^{\mathrm{ab}}$ & $89.0 \pm 0.41^{b c}$ & $88.9 \pm 0.19^{b c}$ & $89.0 \pm 0.14^{b c}$ & $88.3 \pm 0.86^{c}$ \\
\hline Crude lipid & $90.9 \pm 0.18^{\mathrm{ab}}$ & $92.1 \pm 0.23^{a}$ & $91.8 \pm 0.28^{\mathrm{ab}}$ & $91.6 \pm 1.61^{\mathrm{ab}}$ & $89.2 \pm 1.12^{\mathrm{b}}$ & $88.8 \pm 0.16^{\mathrm{b}}$ \\
\hline Gross energy & $79.0 \pm 0.60^{a}$ & $78.5 \pm 1.28^{\mathrm{a}}$ & $74.9 \pm 2.04^{b}$ & $77.6 \pm 0.08^{\mathrm{ab}}$ & $78.2 \pm 0.18^{\mathrm{ab}}$ & $79.0 \pm 1.22^{\mathrm{a}}$ \\
\hline \multicolumn{7}{|c|}{ Essential amino acids (EAA) } \\
\hline Arginine & $97.1 \pm 0.23^{a}$ & $96.5 \pm 0.33^{\mathrm{ab}}$ & $96.0 \pm 0.22^{\mathrm{b}}$ & $96.1 \pm 0.07^{\mathrm{b}}$ & $95.9 \pm 0.14^{b}$ & $96.0 \pm 0.21^{\mathrm{b}}$ \\
\hline Histidine & $94.9 \pm 0.35$ & $94.6 \pm 0.42$ & $94.2 \pm 0.30$ & $94.4 \pm 0.17$ & $94.4 \pm 0.18$ & $94.0 \pm 0.46$ \\
\hline Isoleucine & $91.1 \pm 0.40^{a}$ & $90.5 \pm 0.69^{a b}$ & $89.3 \pm 0.35^{b}$ & $89.3 \pm 0.41^{b}$ & $89.2 \pm 0.22^{b}$ & $89.3 \pm 0.67^{b}$ \\
\hline Leucine & $92.6 \pm 0.36^{\mathrm{a}}$ & $92.0 \pm 0.59^{\mathrm{ab}}$ & $91.0 \pm 0.33^{b}$ & $90.8 \pm 0.37^{b}$ & $90.8 \pm 0.28^{b}$ & $90.7 \pm 0.64^{b}$ \\
\hline Threonine & $91.9 \pm 0.28^{a}$ & $91.3 \pm 0.57^{\mathrm{ab}}$ & $90.5 \pm 0.33^{b}$ & $90.7 \pm 0.34^{b}$ & $90.6 \pm 0.34^{b}$ & $90.6 \pm 0.41^{b}$ \\
\hline Methionine & $96.8 \pm 0.16^{a}$ & $96.3 \pm 0.36^{\mathrm{ab}}$ & $95.8 \pm 0.23^{b c}$ & $96.0 \pm 0.25^{a b c}$ & $95.5 \pm 0.46^{\mathrm{bc}}$ & $95.2 \pm 0.04^{c}$ \\
\hline Valine & $91.0 \pm 0.15^{a}$ & $90.6 \pm 0.69^{a b}$ & $89.1 \pm 0.37^{c}$ & $89.4 \pm 0.42^{b c}$ & $89.1 \pm 0.30^{c}$ & $89.3 \pm 0.69^{b c}$ \\
\hline Lysine & $95.6 \pm 0.27^{a}$ & $95.1 \pm 0.35^{\mathrm{ab}}$ & $94.7 \pm 0.18^{\mathrm{b}}$ & $94.6 \pm 0.06^{\mathrm{bc}}$ & $94.4 \pm 0.06^{b c}$ & $93.9 \pm 0.38^{c}$ \\
\hline Phenylalanine & $92.1 \pm 0.50^{a}$ & $91.7 \pm 0.79^{\mathrm{ab}}$ & $89.9 \pm 0.51^{c}$ & $90.4 \pm 0.24^{\mathrm{bc}}$ & $90.7 \pm 0.23^{\mathrm{abc}}$ & $90.8 \pm 0.58^{\mathrm{abc}}$ \\
\hline
\end{tabular}

${ }^{1}$ Means of three replicate tanks. Values with different superscripts in rows are significantly different $(P<0.05)$.

Table 5. Whole body and muscle proximate composition of juvenile yellow catfish fed test diets for 8 weeks. ${ }^{1}$

\begin{tabular}{|c|c|c|c|c|c|c|}
\hline \multirow[b]{2}{*}{ Parameters } & \multicolumn{6}{|c|}{ Diet groups } \\
\hline & Control & BSF10 & BSF15 & BSF20 & BSF25 & BSF30 \\
\hline \multicolumn{7}{|l|}{ Whole body ${ }^{2}$} \\
\hline Crude protein (\%) & $13.8 \pm 0.18$ & $14.1 \pm 0.80$ & $13.6 \pm 0.78$ & $13.8 \pm 1.31$ & $13.3 \pm 0.25$ & $12.9 \pm 0.17$ \\
\hline Crude lipid (\%) & $4.43 \pm 0.54$ & $4.69 \pm 0.39$ & $5.45 \pm 0.09$ & $4.76 \pm 0.39$ & $4.43 \pm 0.02$ & $5.00 \pm 0.28$ \\
\hline Ash (\%) & $2.99 \pm 0.10$ & $2.98 \pm 0.16$ & $2.83 \pm 0.15$ & $2.77 \pm 0.19$ & $2.77 \pm 0.06$ & $2.58 \pm 0.08$ \\
\hline Moisture (\%) & $77.7 \pm 0.70$ & $76.8 \pm 1.40$ & $76.8 \pm 1.04$ & $77.3 \pm 1.98$ & $78.2 \pm 0.32$ & $78.4 \pm 0.24$ \\
\hline \multicolumn{7}{|l|}{ Muscle $^{2}$} \\
\hline Crude protein (\%) & $16.5 \pm 0.21$ & $16.9 \pm 0.16$ & $16.7 \pm 0.03$ & $17.0 \pm 0.21$ & $16.8 \pm 0.18$ & $16.6 \pm 0.09$ \\
\hline Crude lipid (\%) & $1.57 \pm 0.12$ & $1.82 \pm 0.07$ & $1.61 \pm 0.02$ & $1.75 \pm 0.09$ & $1.78 \pm 0.08$ & $1.76 \pm 0.14$ \\
\hline Ash (\%) & $1.07 \pm 0.03^{b}$ & $1.11 \pm 0.03^{\mathrm{ab}}$ & $1.11 \pm 0.03^{\mathrm{ab}}$ & $1.11 \pm 0.03^{\mathrm{ab}}$ & $1.18 \pm 0.02^{\mathrm{a}}$ & $1.09 \pm 0.04^{\mathrm{ab}}$ \\
\hline Moisture (\%) & $79.7 \pm 0.26$ & $79.3 \pm 0.42$ & $79.5 \pm 0.26$ & $79.2 \pm 0.27$ & $79.1 \pm 0.06$ & $79.5 \pm 0.19$ \\
\hline \multicolumn{7}{|c|}{ Essential amino acids in muscle $(\%)^{3}$} \\
\hline Arginine & $5.13 \pm 0.13$ & $5.03 \pm 0.14$ & $4.99 \pm 0.14$ & $4.98 \pm 0.09$ & $4.87 \pm 0.13$ & $4.94 \pm 0.04$ \\
\hline Histidine & $2.14 \pm 0.03$ & $2.10 \pm 0.04$ & $2.13 \pm 0.04$ & $2.14 \pm 0.01$ & $2.06 \pm 0.02$ & $2.10 \pm 0.02$ \\
\hline Isoleucine & $3.88 \pm 0.06$ & $3.75 \pm 0.07$ & $3.81 \pm 0.08$ & $3.78 \pm 0.02$ & $3.74 \pm 0.06$ & $3.74 \pm 0.02$ \\
\hline Leucine & $6.84 \pm 0.09$ & $6.69 \pm 0.11$ & $6.73 \pm 0.12$ & $6.76 \pm 0.04$ & $6.58 \pm 0.11$ & $6.75 \pm 0.04$ \\
\hline Threonine & $3.95 \pm 0.03$ & $3.89 \pm 0.05$ & $3.90 \pm 0.04$ & $3.93 \pm 0.03$ & $3.84 \pm 0.06$ & $3.94 \pm 0.03$ \\
\hline Methionine & $2.35 \pm 0.02^{a}$ & $2.30 \pm 0.03^{\mathrm{ab}}$ & $2.30 \pm 0.03^{\mathrm{ab}}$ & $2.32 \pm 0.02^{\mathrm{ab}}$ & $2.26 \pm 0.03^{b}$ & $2.32 \pm 0.03^{\mathrm{ab}}$ \\
\hline Valine & $3.96 \pm 0.07$ & $3.83 \pm 0.06$ & $3.89 \pm 0.08$ & $3.88 \pm 0.04$ & $3.79 \pm 0.06$ & $3.82 \pm 0.03$ \\
\hline Lysine & $8.15 \pm 0.13$ & $7.97 \pm 0.12$ & $7.98 \pm 0.15$ & $8.07 \pm 0.09$ & $7.86 \pm 0.12$ & $8.06 \pm 0.05$ \\
\hline Phenylalanine & $3.53 \pm 0.05^{a}$ & $3.46 \pm 0.05^{\mathrm{ab}}$ & $3.51 \pm 0.06^{\mathrm{ab}}$ & $3.50 \pm 0.01^{\mathrm{ab}}$ & $3.38 \pm 0.04^{b}$ & $3.48 \pm 0.02^{\mathrm{ab}}$ \\
\hline
\end{tabular}

${ }^{1}$ Means of three replicate tanks. Values with different superscripts in rows are significantly different $(P<0.05)$.

2 expressed on a wet-weight basis.

3 expressed on a dry-weight basis. 
Table 6. Plasma parameters of juvenile yellow catfish fed test diets for 8 weeks. ${ }^{1}$

${ }^{1}$ Means of three replicate tanks. Values with different superscripts in columns are significantly different $(P<0.05)$.

${ }^{2}$ ALB: albumin.

${ }^{3}$ GLB: globin.

${ }^{4} \mathrm{CHO}$ : cholesterol.

${ }^{5} \mathrm{GLU}$ : glucose.

${ }^{6}$ UREA: urea.

\begin{tabular}{|c|c|c|c|c|c|c|c|}
\hline $\begin{array}{l}\text { Diet } \\
\text { group }\end{array}$ & $A L B(g / L)^{2}$ & $G L B(g / L)^{3}$ & $\begin{array}{c}\mathrm{CHO} \\
(\mathrm{mmol} / \mathrm{L})^{4}\end{array}$ & $\begin{array}{c}G L U \\
(\mathrm{mmol} / \mathrm{L})^{5}\end{array}$ & $\begin{array}{c}\text { UREA } \\
(\mathrm{mmol} / \mathrm{L})^{6}\end{array}$ & $\begin{array}{l}\text { Inhibition } \\
\text { of } \\
\text { superoxide } \\
\text { radical } \\
\text { anion } \\
\text { generation } \\
(U / L)\end{array}$ & $N O(\mu \mathrm{mol} / \mathrm{L})$ \\
\hline Control & $10.4 \pm 0.23$ & $18.4 \pm 0.43^{\mathrm{ab}}$ & $4.24 \pm 0.09^{b}$ & $6.19 \pm 0.29$ & $0.83 \pm 0.12$ & $164 \pm 2.96^{\mathrm{a}}$ & $14.4 \pm 6.96^{\mathrm{b}}$ \\
\hline BSF10 & $9.90 \pm 0.70$ & $17.4 \pm 0.29^{b}$ & $4.54 \pm 0.32^{\mathrm{b}}$ & $5.82 \pm 0.10$ & $0.63 \pm 0.09$ & $158 \pm 1.24^{\mathrm{a}}$ & $25.7 \pm 6.78^{\mathrm{ab}}$ \\
\hline BSF15 & $10.3 \pm 0.19$ & $18.7 \pm 0.36^{\mathrm{ab}}$ & $5.00 \pm 0.19^{\mathrm{ab}}$ & $6.13 \pm 0.73$ & $0.83 \pm 0.09$ & $162 \pm 2.44^{\mathrm{a}}$ & $23.2 \pm 6.66^{\mathrm{ab}}$ \\
\hline BSF20 & $9.83 \pm 0.60$ & $19.2 \pm 0.44^{\mathrm{a}}$ & $5.08 \pm 0.12^{\mathrm{ab}}$ & $6.84 \pm 0.31$ & $0.73 \pm 0.12$ & $149 \pm 5.03^{\mathrm{ab}}$ & $25.0 \pm 5.29^{\mathrm{ab}}$ \\
\hline BSF25 & $10.2 \pm 0.00$ & $18.1 \pm 0.48^{\mathrm{ab}}$ & $4.88 \pm 0.15^{\mathrm{ab}}$ & $5.90 \pm 0.45$ & $0.73 \pm 0.03$ & $165 \pm 1.90^{\mathrm{a}}$ & $22.4 \pm 7.58^{\mathrm{ab}}$ \\
\hline BSF30 & $9.03 \pm 0.64$ & $17.4 \pm 0.77^{b}$ & $5.65 \pm 0.52^{\mathrm{a}}$ & $7.00 \pm 2.16$ & $0.90 \pm 0.12$ & $140 \pm 11.4^{b}$ & $36.1 \pm 6.30^{\mathrm{a}}$ \\
\hline
\end{tabular}

\section{Discussion}

Growth performance. The results presented above showed that dietary FM replacement affected the growth performance of juvenile yellow catfish when the degree of replacement was above $20 \%$. Thus, it was possible to replace the FM protein with BSF protein up to $20 \%$. This corresponds to approximately $8.9 \%$ of the total crude protein in the diet. Substantially higher replacement levels were successful in other fish species: $25 \%$ or $50 \% \mathrm{FM}$ replacement in rainbow trout (St-Hilaire et al., 2007a; Sealey et al., 2011), and $50 \%$ in tilapia fry (Rana et al., 2015). The crude protein content of the BSF used in the studies cited above was higher than the BSF meal examined in this study, which may explain why higher FM replacement levels were not viable in this case. Replacement of $17 \%$ FM with BSF significantly impaired growth performance even though the BSF had higher crude protein content than the FM (Kroeckel et al., 2012), indicating that the upper limit on FM replacement is not determined solely by the protein content of the BSF, but also appears to be related to differences between species, variation in the nutritional qualities (protein, lipid and/or some essential amino acids) of the BSF meal between studies (Newton et al., 2005; Sealy et al., 2011; Kroeckel et al., 2012), differences in the digestibility or palatability of BSF (such as chitin, which is indigestible to many fish species because they lack chitinase activity) and the presence of antinutritional factors in BSF (Rust, 2002; Kroeckel et al., 2012).

Apparent Digestibility Coefficients. Feed digestibility is an important factor to consider when evaluating utilization of a feed. In this study, we used a scoop net (178 $\mu \mathrm{m}$ mesh) to collect fecal matter from the tank bottom rather than killing selected fish and dissecting the posterior intestine (Kroeckel et al., 2012) or siphoning. Collecting feces by dissection of the posterior intestine can substantially reduce the degradation and dispersal of the feces but was not suitable in this case because we examined limited numbers of small $(20 \mathrm{~g})$ fish. Siphoning was not used because it can cause dispersal of the feces for suction and is unsuitable for smaller fish, while the use of a scoop net has the advantage of minimizing loss of water and nutrients from the feces. In this study, the ADCs of dry matter, crude protein, and amino acids, declined when the level of FM replacement exceeded $10 \%$, while the ADC of crude lipids was $20 \%$. This differed from another study where ADC was not affected by the inclusion of BSF meal in European sea bass Dicentrarchus labrax diets up to $19.5 \%$ (López, 2015). A similar result was obtained from a turbot feeding trial that suggested that the ADC of BSF reduces the overall ADC of BSF containing diets (Kroeckel et al., 2012). In our study, although there were statistical differences of ADCs, these differences were so slight that we considered the possibility 
Hu et al.

that they were the result of different collection methods. Whether the difference of ADCs is caused by the collection method or the digestibility of BSF, a lengthier feeding trial may be needed.

Whole body and muscle proximate composition. The rate of protein and lipid synthesis and deposition in fish muscle depends on a wide range of dietary differences that can cause changes in body composition on a wet matter basis (Hansen et al., 2007). In this study, there were no significant differences in crude protein, crude lipid, and moisture content in whole body and muscle. However, another study found that in rainbow trout, the crude lipid content of the whole body and muscle tissue decreased significantly as the amount of BSF increased (Kroeckel et al. 2012; Sealey et al. 2011). It has been suggested that the defatting process influences the level of the lipids and that this may have reduced the lipid bioavailability (Kroeckel et al. 2012). The experimental diets also affected ash content in the muscles. Insect exoskeletons are notably rich in mineral salts, so replacing FM with BSF could substantially change the mineral salt content of the diets and affect the ash content of fish muscle. Although there were differences in the distribution of essential amino acids (e.g. lysine) between the experimental diets, this did not cause any significant changes in the amino acid profile of fish muscle when FM was replaced with levels of up to $20 \%$. These results suggest that for replacement levels of $20 \%$ or less, the adverse effects of FM replacement on protein accretion are very limited. This is similar to the body composition results of rainbow trout and Pacific white shrimp (St-Hilaire et al., 2007; Cummins et al., 2017).

Blood parameters. Blood parameters are important for detecting physiological stress response (due to factors such as temperature, photoperiod, density, salinity, or nutrition) as well as general fish health. Our results clearly showed that dietary BSF increased the $\mathrm{CHO}$ content of the plasma at high replacement levels. We noticed that the pre-pupal BSF larvae fed with kitchen waste had a crude lipid content of around $33.45 \%$, which is much greater than that of FM. Consequently, we reduced the amount of soybean oil in the diets while maintaining an isonitrogenous and isolipidic level. We speculated that the lipids in diets may not have been effectively digested, and caused abnormal cholesterol metabolism. The inhibition of superoxide radical anion generation is an index used to evaluate the ability of tissue to suppress formation of the superoxide radical anion. NO is a highly reactive free radical with an unpaired electron that reacts rapidly with superoxide to form the highly reactive molecule peroxynitrite (ONOO-), triggering harmful events (Turko et al., 2001). High levels of NO are associated with increased oxidative stress. Black soldier fly larva and pupa extract have antioxidant properties and these fractions can be utilized to develop functional feedstuff (Park et al. 2014). However, in this study, fish fed $30 \%$ replacement diets exhibited a reduced capacity to inhibit superoxide formation and higher levels of NO than those fed the control diet, indicating that high levels of FM replacement could attribute to oxidative stress; the antioxidant activity of BSF itself at this replacement level has no effect.

In conclusion, the results of this study showed that up to $20 \%$ of FM protein can be replaced with BSF protein without causing significant negative effects on the SGR, FCR, whole body and muscle proximate composition, or blood parameters of juvenile yellow catfish. BSF protein is, therefore, a potential protein source for yellow catfish diets.

\section{Acknowledgements}

This research was supported by the Science and technology planning project of Guangdong No. 2014A020208068; 2015A040404033), Marine fishery science and industrial development project of Guangdong No. A201501C06, Science and technology planning project of Tianhe region No. 201408YG013. 


\section{References}

AOAC (Association of Official Analytical Chemists).1995. Official Methods of Analysis, 16th ed. AOAC, Arlington, VA.

Adeniyi, Victoria O., Folorunsho, C. 'Yemi, 2015. Performance of Clarias gariepinus (Burchell, 1822) fed dietary levels of black soldier fly, Hermetia illucens (Linnaeus, 1758) prepupae meal as a protein supplement. Int J Res Fish Aquacult., 5(3), 89-93.

Bradford M. M. 1976. A rapid and sensitive method for the quantization of microgram quantities of protein utilizing the principle of protein-dye binding. Anal Biochem 72 (s12), 248-254.

Bondari K. and D.C. Sheppard, 1981. Soldier fly larvae as feed in commercial fish production. Aquaculture 24 (81), 103-9.

Cummins Jr. V. C., Rawles S. D., Thompson K. R., Velasquez A., Kobayashi Y., Hager J. and C. D. Webster, 2017. Evaluation of black soldier fly (Hermetia illucens) larvaemeal as partial or total replacement of marine fish meal in practical diets for Pacific white shrimp (Litopenaeus vannamei). Aquaculture 473, 337-344.

Hansen A. C., Rosenlund G., Karlsen Ø., Koppe W. and G. I. Hemre, 2007. Total replacement of fish meal with plant proteins in diets for Atlantic cod (Gadus morhua L.). I-Effects on growth and protein retention. Aquaculture 272 (1-4), 599-611.

Hem S., Toure S., Sagbla C. and M. Legendre, 2008. Bioconversion of palm kernel meal for aquaculture: Experiences from the forest region (Republic of Guinea). Afr J Biotechnol 7 (8), 1192-1198.

López A. S.2015. Potential of pre-pupae meal of the Black Soldier Fly (Hermetia illucens) as fish meal substitute: effect on growth performance and digestibility in European sea bass (Dicentrarchus labrax). Vniversitat politecnca, Valencia.

Kroeckel S., Harjes A. G. E., Roth I., Katz H., Wuertz S., Susenbeth A. and C. Schulz, 2012. When a turbot catches a fly: Evaluation of a pre-pupae meal of the Black Soldier Fly (Hermetia illucens) as fish meal substitute-Growth performance and chitin degradation in juvenile turbot (Psetta maxima). Aquaculture 364:345-352.

Newton G. L., Sheppard D. C., Watson D. W. Burtle G. J. Dove C. R. Tomberlin J. K. and E. E. Thelen, 2005. The black soldier fly, Hermetia illucens, as a manure management/resource recovery tool. Proceedings of the Symposium on the State of the Science of Animal Manure and Waste Management, January 5-7, San Antonio, Texas, USA.

Park K., Choi J., Nam S., Kim S., Kwak K., Lee S., and S. Nho, 2014. Antioxidant activities of black soldier fly, Hermetia illucens. J Seric Entomol Sci 52(2):142-146.

Rana K. M. S., Salam M. A., HashemI S. and Md. A. Islam, 2015. Development of black soldier fly larvae production technique as an alternate fish feed. Int $\mathrm{J}$ Res Fish Aquacult., 5(1), 41-47.

Rust M.B. 2002. Nutritional Physiology. In J.E Halver and R.W. Hardy (Editors.): Fish Nutrition. 3rd Edition, Academic press, New York, U.S.A. PP 368-446.

St-Hilaire S., Sheppard C., Tomberlin J. K., Irving S., Newton L. M., McGuire A., Mosley E. E., Hardy R. W. and W. M. Sealey, 2007a. Fly prepupae as a feedstuff for rainbow trout Oncorhynchus mykiss. J World Aquacult Soc 38 (1):309-313.

Sealey W. M., Gaylord T. G., Barrows F. T., Tomberlin J. K., McGuire M. A., Ross C. and S. St-Hilaire, 2011. Sensory analysis of rainbow trout, Oncorhynchus mykiss, fed enriched black soldier fly prepupae, Hermetia illucens. J World Aquacult Soc 42 (1), 34-45.

Stamer A., Wessless S., Neidigk R. and G. HoerstgenSchwark, 2014. Black soldier fly (Hermetia illucens.) larvae meal as an example of a new feeding ingredients class in aquaculture diets. Proceeding of the 4 th ISOFAR SCIENTIFIC Conference: Building organic bridges at the Organic World Congress, Islanbul, Turkey.

Turko I. V., Marcondes S. and F. Murad, 2001. Diabetes-associated nitration of tyrosine and inactivation of succinyl-CoA: 3-oxoacid CoA-transferase. Am J Physiol Heart Circ Physiol 281 (6), H2289-H2294. 